\title{
The significance of haemochromatosis gene mutations in the general population: implications for screening
}

\author{
M J Burt, P M George, J D Upton, J A Collett, C M A Frampton, T M Chapman,
} T A Walmsley, B A Chapman

\begin{abstract}
Background-Haemochromatosis is associated with mutations in the $H F E$ gene but the significance of these mutations in the general population is unknown.

Aims-To determine the frequency of $H F E$ gene mutations in the general population, their effect on serum iron indexes, and their role in screening for haemochromatosis.

Methods-Deoxyribonucleic acid (DNA) from 1064 randomly selected subjects was analysed for the C282Y and H63D mutations in the $H F E$ gene. Serum iron, transferrin saturation, and ferritin were measured and individuals with increased iron indexes were investigated to confirm or exclude a clinical diagnosis of haemochromatosis.

Results-Mutations were identified in 409 individuals $(38.4 \%)$ with heterozygote (carrier) frequencies of $13.2 \%$ and $24.3 \%$ for the C282Y and H63D mutations respectively. Heterozygosity for either mutation significantly increased serum iron and transferrin saturation but despite a similar trend for ferritin, this was only significant for C282Y homozygotes. Five individuals $(0.47 \%)$ were homozygous for the C282Y mutation, three of whom had haemochromatosis confirmed by liver biopsy $(0.28 \%)$. The other two $\mathrm{C} 282 \mathrm{Y}$ homozygotes would not have been detected by phenotypic screening alone. Conclusions-HFE mutations are present in $38.4 \%$ of the population, affect serum iron indexes, and are important determinants of iron status. The population frequency of genetically defined haemochromatosis (C282Y homozygosity) is approximately one in 200 and is higher than the prevalence of clinically apparent haemochromatosis.

(Gut 1998;43:830-836)
\end{abstract}

Keywords: haemochromatosis; iron overload; HFE gene; screening

Haemochromatosis is a common autosomal recessive disorder of iron metabolism occurring with a prevalence of 0.2 to $0.5 \%$ in Caucasian populations. ${ }^{1-6}$ It is characterised by the excessive absorption of dietary iron and a progressive rise in body iron stores which may result in cirrhosis, diabetes, cardiac failure and arrhythmias, hypogonadism, arthritis, hepato- cellular carcinoma, and reduced life expectancy. ${ }^{78}$ The morbidity and mortality of haemochromatosis can be reduced by venesection to remove the iron burden, ${ }^{9}$ and early diagnosis is important as the life expectancy of treated non-cirrhotic patients is normal. ${ }^{10-12}$

The diagnosis of haemochromatosis has traditionally relied on the demonstration of increased iron stores and the exclusion of secondary iron overload. Diagnosis is therefore dependent on phenotypic expression but this is related to age and can be modified by non-genetic factors such as dietary composition, blood donation, menstruation, pregnancy, and pathological blood loss. ${ }^{7}$ The recent identification of the haemochromatosis gene has important implications for diagnosis and screening. ${ }^{13}$ Originally termed HLA-H, now designated $H F E,{ }^{14}$ the gene encodes a 343 amino acid protein with homology to major histocompatibility class I molecules. ${ }^{13}$ Two missense mutations have been identified in this gene. The first causes a substitution of cysteine with a tyrosine residue at position 282 (C282Y) and homozygosity for this mutation has been identified in $64-100 \%$ of reported patients. ${ }^{13}{ }^{15-18}$ The significance of the second mutation, a substitution of histidine with aspartate at position 63 (H63D), is controversial. ${ }^{19}$ Although homozygosity for this mutation is not clearly associated with haemochromatosis, some patients are compound heterozygotes, that is, heterozygous for both the $\mathrm{C} 282 \mathrm{Y}$ and H63D mutation. ${ }^{13}{ }^{16-20}$

The aims of this study were to determine the frequency of the two $H F E$ gene mutations in a large random population sample, to determine their effect on serum iron indexes, and to evaluate their use in screening for haemochromatosis.

\section{Methods}

SUBJECTS

The study was designed to obtain a random sample of 1000 subjects representative of the adult population of Christchurch, New Zealand, a city with a predominantly European population of 350000 . A list of 4000 names was randomly generated from the 1996 electoral rolls (approximately 93\% of the population over 18 years of age are enrolled voters) and was used to recruit subjects sequentially. Subjects were contacted by telephone and invited to participate by a trained interviewer. If subjects declined to participate, limited demographic data were requested and
Accepted for publication 7 July 1998 
Table 1 Demographic information: study population versus non-participants

\begin{tabular}{|c|c|c|c|}
\hline & $\begin{array}{l}\text { Study population } \\
(n=1064)\end{array}$ & $\begin{array}{l}\text { Non-participants* } \\
(n=2446)\end{array}$ & $p$ Value \\
\hline$\underset{n}{M}$ Mean age (years) $\dagger$ & $\begin{array}{l}50.2 \\
1064\end{array}$ & $\begin{array}{l}50.4 \\
676\end{array}$ & NS \\
\hline $\operatorname{Sex} \ddagger$ & & & $<0.001$ \\
\hline Male & $423(39.8 \%)$ & $1113(46.4 \%)$ & \\
\hline Female & $641(60.2 \%)$ & $1286(53.6 \%)$ & \\
\hline Total & 1064 & 2399 & \\
\hline Ethnicity† & & & NS \\
\hline European & $1021(96.0 \%)$ & $641(94.1 \%)$ & \\
\hline Maori & $23(2.2 \%)$ & $15(2.2 \%)$ & \\
\hline Pacific Islander & $8(0.8 \%)$ & $7(1.0 \%)$ & \\
\hline Other & $12(1.1 \%)$ & $18(2.6 \%)$ & \\
\hline Total & 1064 & 681 & \\
\hline Employment status $\ddagger$ & & & $<0.001$ \\
\hline Unemployed & $26(2.5 \%)$ & $97(4.3 \%)$ & \\
\hline Homemaker & $173(16.7 \%)$ & $324(14.3 \%)$ & \\
\hline Retired & $230(22.2 \%)$ & $361(15.9 \%)$ & \\
\hline Employed & $559(53.9 \%)$ & $1289(59.6 \%)$ & \\
\hline Student & $50(4.8 \%)$ & $196(8.6 \%)$ & \\
\hline Total & 1038 & 2267 & \\
\hline
\end{tabular}

*Non-participants are those subjects, randomly selected from the electoral rolls, who were approached but not recruited.

†Information obtained from interview (age, ethnicity).

$\ddagger$ Information extracted from the electoral roll (sex, employment status) when available.

recorded if given. If subjects were not able to be contacted by telephone they were sent an information sheet and asked to contact an interviewer. Volunteers attended Christchurch Hospital, completed a questionnaire, and provided a fasting blood specimen. Subjects unable to come to the hospital were visited at home. Informed consent was obtained from all subjects and the study protocol was approved by the Southern Regional Health Authority's Ethics Committee.

In total 3510 adults were invited to participate: $2032(57.9 \%)$ by telephone and 1478 $(42.1 \%)$ by letter. Final enrolment was 1064 (30.3\% of the 3510 subjects approached) and included 52 individuals who were visited at home. A greater proportion of subjects initially contacted by telephone $(42.3 \%)$ participated in the study compared with those contacted by letter $(13.8 \%)$. The reasons for nonparticipation $(n=2446)$ were: not able to be contacted (errors in the electoral roll or change of address) in $112(4.6 \%)$; refusal in 744 $(30.4 \%)$; initial agreement but failure to attend in $357(14.6 \%)$; and no response to a letter of invitation in $1233(50.4 \%)$. When available, information on sex and employment status was extracted from the electoral rolls and analysis indicated that the study sample contained a higher proportion of females and retirees, and proportionately fewer students and unemployed subjects compared with those who did not participate in the study (table 1). Age and racial background are not available from the electoral rolls but were supplied by more than $90 \%$ of the 735 subjects who were contacted by telephone but declined to participate, and were not significantly different from the study population (table 1).

Fasting blood samples were collected from all 1064 study participants. Subjects with a transferrin saturation of greater than $55 \%$ were asked to provide a further fasting blood specimen for repeat iron analyses. Those subjects with a consistently elevated transferrin saturation and a consistently elevated serum ferritin concentration (males greater than $300 \mu \mathrm{g} / \mathrm{l}$, females greater than $160 \mu \mathrm{g} / \mathrm{l})$ were reviewed and offered liver biopsy. Biopsy specimens were stained with Perls' Prussian blue and the stainable iron was graded $0-4 .^{21}$ The hepatic iron concentration was determined by atomic absorption spectrophotometry and hepatic iron index ( $\mu \mathrm{mol}$ iron/g dry tissue/year) was calculated..$^{23} \mathrm{~A}$ hepatic iron index greater than 2.0 is consistent with homozygous haemochromatosis. ${ }^{22}$ All patients homozygous for the C282Y mutation were reviewed and liver biopsy was performed if their iron indexes met the above criteria.

SERUM IRON INDEXES

Serum was separated and stored at $-20^{\circ} \mathrm{C}$ until analysis. The serum iron concentration, unbound iron binding capacity, and serum ferritin concentration were all measured simultaneously on a Hitachi 717 analyser (Boehringer Mannheim, Indianapolis, Indiana) according to the manufacturer's instructions using reagents supplied by Boehringer. Iron and unbound iron binding capacity were measured using FerroZine (no. 1553712) and added together to determine the total iron binding capacity. Iron was divided by the total iron binding capacity and multiplied by 100 to calculate the percentage saturation (transferrin saturation). Ferritin was measured using latex bound antibodies (Tina-quant Ferritin no. 1661400) and calibrated with Preciset Ferritin (no. 1056689). The manufacturer's stated reference ranges for serum ferritin (males 30-300 $\mu \mathrm{g} / \mathrm{l}$, females $10-160 \mu \mathrm{g} / \mathrm{l}$ ) were used to define iron deficiency and possible iron overload.

\section{ANALYSIS OF HFE GENE MUTATIONS}

DNA was extracted from peripheral blood ${ }^{24}$ and stored at $-20^{\circ} \mathrm{C}$ for analysis of the $H F E$ gene. The C282Y mutation creates an Rsa I restriction site and the H63D mutation abolishes a Bcl I site allowing detection of the two mutations by polymerase chain reaction (PCR) amplification and restriction enzyme digestion. ${ }^{25}$ Primer sequences were those described by Feder et al..$^{13}$ PCR was performed in $50 \mu \mathrm{l}$ reactions containing $12.5 \mathrm{pmol}$ of each primer, $200 \mu \mathrm{mol} / 1$ deoxynucleoside triphosphates, $1.5 \mathrm{mmol} / 1 \mathrm{MgCl}_{2}, 0.5 \mathrm{U}$ Taq polymerase, and $5 \mu \mathrm{l}$ of the DNA preparation. The products were digested by addition of restriction enzyme and analysed by electrophoresis in $4 \%$ agarose gels.

\section{STATISTICAL ANALYSIS}

Demographic parameters were compared between the study population and the nonparticipants, and between genotype groups using $\chi^{2}$ or $t$ tests as appropriate. The proportion of iron deficient individuals in each genotype was compared using $\chi^{2}$ tests or Fisher's exact test when expected frequencies were low. The effect of genotype and sex on iron indexes was assessed using analysis of variance (ANOVA) and when this was significant for genotype, pairwise comparisons between genotypes were made using Fisher's least significant difference test. In the case of ferritin the data were $\log$ transformed prior to analysis to 
Table 2 HFE genotypes and sex corrected mean serum iron indexes for the study population

\begin{tabular}{|c|c|c|c|c|c|c|}
\hline Genotype & $\begin{array}{l}\text { No of subjects } \\
(n=1064)\end{array}$ & $\begin{array}{l}\text { Frequency } \\
(\%)\end{array}$ & $\begin{array}{l}\text { Serum iron } \\
\text { concentration }(\mu \mathrm{mol} / \mathrm{l})\end{array}$ & $\begin{array}{l}\text { Total iron binding } \\
\text { capacity }(\mu m o l l l)\end{array}$ & $\begin{array}{l}\text { Transferrin } \\
\text { saturation (\%) }\end{array}$ & $\begin{array}{l}\text { Serum ferritin } \\
\text { concentration }(\mu g / l)\end{array}$ \\
\hline C282Y homozygous & 5 & 0.5 & $34.3^{\star \star \star}(5.4)$ & $41.3^{\star \star \star}(4.6)$ & $83.4^{\star \star \star}(14.4)$ & $397.2^{\star \star}(179.8-875.9)$ \\
\hline Compound heterozygosity & 19 & 1.8 & $21.4^{\star \star}(4.5)$ & $51.8^{\star \star \star}(7.7)$ & $42.0^{\star \star \star}(9.3)$ & $127.3(84.5-191.3)$ \\
\hline H63D homozygous & 24 & 2.3 & $21.2^{\star \star}(6.4)$ & $54.4^{\star \star}(10.0)$ & $39.3^{\star \star \star}(11.3)$ & $107.5(74.7-154.6)$ \\
\hline $\mathrm{C} 282 \mathrm{Y}$ heterozygous & 121 & 11.4 & $18.7 \dagger(5.7)$ & $55.1^{\star \star \star}(8.1)$ & $34.7^{\star \star \star}(12.1)$ & $93.0(79.0-109.3)$ \\
\hline H63D heterozygous & 240 & 22.6 & $18.8^{\star \star}(6.6)$ & $57.5^{\star}(9.4)$ & $33.4^{\star \star \star}(12.8)$ & $90.7(80.8-101.7)$ \\
\hline Normal (no $H F E$ mutation) & 655 & 61.6 & $17.7(5.7)$ & $59.1(9.5)$ & $30.5(10.2)$ & $86.9(81.0-93.2)$ \\
\hline
\end{tabular}

Results expressed as mean (SD) except for serum ferritin concentrations which are expressed as the geometric mean (95\% confidence intervals).

${ }^{\star} \mathrm{p}<0.05,{ }^{\star \star} \mathrm{p}<0.01,{ }^{\star \star \star} \mathrm{p}<0.001,+\mathrm{p}=0.051$.

normalise the distribution. The effect of genotype on ferritin concentrations was assessed after correction for both age and sex. All statistical tests were two sided.

\section{Results}

HFE GENOTYPES AND MUTATION FREQUENCIES There were five subjects homozygous for the C282Y mutation $(0.5 \%)$ and $140 \mathrm{C} 282 \mathrm{Y}$ heterozygotes $(13.2 \%), 19$ of whom were were also H63D heterozygotes (compound heterozygotes) (table 2). Twenty four subjects $(2.3 \%)$ were homozygous for the H63D mutation and 259 were heterozygous $(24.3 \%)$ for this mutation either alone $(n=240)$ or as compound heterozygotes $(n=19)$. The gene frequency of the C282Y mutation in this population was therefore 0.070 ; it was 0.144 for the H63D mutation.

In total $38.4 \%$ of the study population carried one or more $H F E$ gene mutations. There were no significant differences in genotype frequencies between males and females or between groups with different employment status. The study sample was composed predominantly of Europeans (New Zealand born European 92.9\%, European migrants $3.1 \%$ ) and there were only 43 non-European subjects (23 Maoris, eight Pacific Islanders, five Asians, three Indians, four others). Mutations were present in seven non-Europeans (one C282Y heterozygote, six H63D heterozygotes), a prevalence of $16.3 \%$ compared with $39.4 \%$ in Europeans. However, this difference was only significant for the C282Y mutation $(p=0.002)$.

HFE GENOTYPE AND IRON INDEXES

Table 2 summarises the serum iron indexes for each genotype. The mean serum iron concentration, transferrin saturation, and serum ferritin concentration were significantly lower in women. There were, however, no significant interactions between sex and genotype for these indexes. This implies that the differences between the sexes were consistent in all genotype groups. All five genotype groups with a mutation had higher mean serum iron concentrations, lower mean total iron binding capacities, and higher mean transferrin saturations than the 655 subjects with no mutations. Although a similar trend was apparent for mean serum ferritin concentrations, this only reached statistical significance for C282Y homozygotes. When compared with simple C282Y heterozygotes, compound heterozygotes had significantly higher mean serum iron and transferrin saturations but the difference in mean serum ferritin concentrations was not significant.

Elevated serum iron indexes have been reported in 10-30\% of heterozygotes identified by HLA typing in family studies; however, the $H F E$ genotype of these individuals is unknown. ${ }^{26-30}$ In order to determine the proportion of genotyped heterozygotes with elevated iron indexes compared with individuals with a normal genotype, we defined the upper limit of the normal range, for transferrin saturation and serum ferritin, from the 655 subjects without a mutation (a genotype specific range).$^{26}$ For transferrin saturation this was defined as the mean plus two standard deviations and was $50.5 \%$. Elevated values were observed in 16 of the $140 \mathrm{C} 282 \mathrm{Y}$ heterozygotes (11.4\%) (table 3). A significantly higher proportion of compound heterozygotes $(26.3 \%)$ had an elevated transferrin saturation compared with simple C282Y heterozygotes $(9.1 \%, p=0.028)$. For ferritin the upper limit of normal was defined as the 97.5 th percentile of the 655 subjects without a mutation and was $428 \mu \mathrm{g} / 1$ for males and $302 \mu \mathrm{g} / 1$ for females. ${ }^{26}$ Fourteen of the $140 \mathrm{C} 282 \mathrm{Y}$ heterozygotes $(10 \%)$ had serum ferritin concentrations exceeding these limits (table 3) but unlike transferrin saturation there were no significant differences between compound and simple C282Y heterozygotes.

A total of 52 subjects ( $4.9 \%)$ were iron deficient as defined by a serum ferritin concentration less than $30 \mu \mathrm{g} / 1$ for males $(\mathrm{n}=24)$ and less

Table 3 Frequency of increased iron indexes in heterozygotes

\begin{tabular}{llll}
\hline Genotype & No of subjects & $\begin{array}{l}\text { Raised transferrin saturationt } \\
(>50.5 \%)\end{array}$ & $\begin{array}{l}\text { Raised serum ferritin } \\
\text { concentration } \neq \\
(M>428, F>302 \mu g / l)\end{array}$ \\
\hline Compound heterozygosity & 19 & $5(26.3)^{\star \star \star}$ & $3(15.8)^{\star \star}$ \\
C282Y heterozygous & 121 & $11(9.1)^{\star \star}$ & $11(9.1)^{\star \star \star}$ \\
H63D heterozygous & 240 & $24(10.0)^{\star \star \star}$ & $10(4.2)$ \\
Normal (no HFE mutation) & 655 & $21(3.2)$ & $16(2.4)$
\end{tabular}

Results are expressed as number (\%).

tMean transferrin saturation of the normal (no $H F E$ gene mutation) genotype group plus two standard deviations.

$\$ 97.5$ th percentile for serum ferritin concentration for male and female subjects without an $H F E$ gene mutation.

${ }_{\star \star \star} \mathrm{p}<0.01,{ }^{\star \star \star} \mathrm{p}<0.001$. 
Table 4 Characteristics of the five C282Y homozygotes

\begin{tabular}{lllllll}
\hline Patient number & Sex $(M / F)$ & Age (years) & $\begin{array}{l}\text { Transferrin } \\
\text { saturation }(\%)\end{array}$ & $\begin{array}{l}\text { Serum ferritin } \\
\text { concentration } \\
(\mu g / l)\end{array}$ & Iron (grade 0-4) & $\begin{array}{l}\text { Hepatic iron index } \\
(\mu m o l / g / \text { year) }\end{array}$ \\
\hline 1 & $\mathrm{~F}$ & 38 & 77 & 283 & 2 & 3.2 \\
2 & $\mathrm{~F}$ & 31 & 83 & 178 & NLB & NLB \\
3 & $\mathrm{~F}$ & 38 & 71 & 334 & 2 & NLB \\
4 & $\mathrm{~F}$ & 20 & 56 & 19 & 3 & 8.0 \\
5 & $\mathrm{M}$ & 71 & 95 & 1167 & 3.0 \\
\hline
\end{tabular}

NLB: these patients did not have consistently raised serum ferritin concentrations (patient 2, repeat value $158 \mu \mathrm{g} / \mathrm{l}$ ) and did not undergo liver biopsy.

than $10 \mu \mathrm{g} / 1$ for females $(\mathrm{n}=28)$. Analysis of the genotype frequencies in these individuals did not identify any significant differences from non-iron deficient subjects. This finding did not change if analysis was restricted to females alone or to females within the reproductive years (18-45).

\section{c282y HOMOZYGOTES}

Five subjects were homozygous for the C282Y mutation (table 4). All had initial and repeat transferrin saturations greater than $55 \%$. Three individuals had persistently elevated serum ferritin concentrations and underwent liver biopsy which showed increased stainable iron within hepatocytes consistent with haemochromatosis. In each case there were no other histological abnormalities and hepatic iron indexes were elevated to levels consistent with haemochromatosis. A fourth subject (subject 2, table 4) did not have a liver biopsy as the repeat serum ferritin was only $158 \mu \mathrm{g} / \mathrm{l}$ and a diagnosis of haemochromatosis affecting an older sister had recently been made in the United States on the basis of liver biopsy findings and response to venesection (5 $\mathrm{g}$ iron removed). This sibling was subsequently confirmed to be a C282Y homozygote. These four patients have commenced therapeutic venesection. The remaining C282Y homozygote (subject 4, table 4) had a repeatedly normal serum ferritin concentration of $17-30 \mu \mathrm{g} / 1$ despite an elevated transferrin saturation. She gave no history of excessive menstrual or other blood loss and she did not

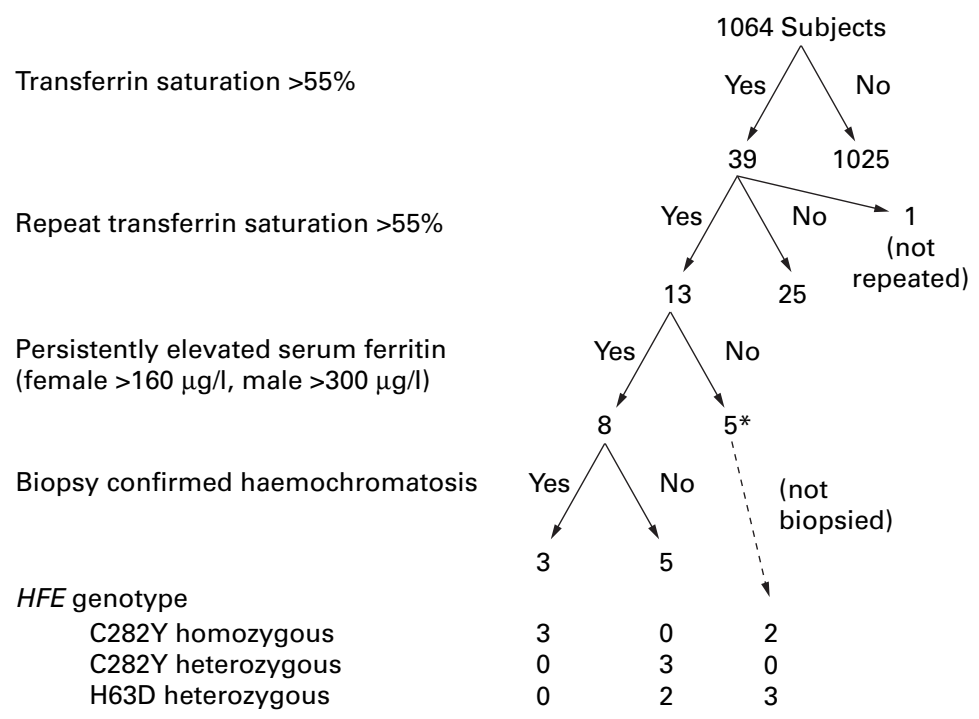

Figure 1 Flow diagram summarising the results of phenotypic screening for haemochromatosis. ${ }^{\star}$ Includes one $C 282 Y$ homozygote with an initial serum ferritin of 178 $\mu \mathrm{g} / \mathrm{l}$ but a repeat value of $158 \mu \mathrm{g} / \mathrm{l}$ who did not have a liver biopsy performed. donate blood. Further investigation identified reduced serum vitamin $\mathrm{B}_{12}(78 \mathrm{pmol} / \mathrm{l}$, normal 114-443) and red cell folate (318 nmol/1, normal 340-1500) but full blood count, ESR, electrolytes, urea, creatinine, liver function tests, and $\mathrm{C}$ reactive protein were all normal. There was a family history of coeliac disease affecting the maternal grandmother but antigliadin and antiendomysial antibodies were negative and small bowel biopsy was normal. There was no history of diarrhoea or abdominal pain; faecal pathogens and parasites were negative. A small bowel series and a dual isotope Schilling test were normal. Her diet was poor and contained only $60-75 \%, 63 \%$, and $75 \%$ of the recommended daily intake for iron, vitamin $\mathrm{B}_{12}$, and folate respectively.

SUBJECTS WITH A TRANSFERRIN SATURATION GREATER THAN $55 \%$

There were 39 subjects (3.7\%) with an initial transferrin saturation greater than $55 \%$ (fig 1 ). Mutations in the $H F E$ gene were present in 28 of the 39 subjects $(71.2 \%)$ and included all genotypes except compound heterozygosity. Further analysis indicated that the C282Y mutation $(\mathrm{p}<0.001)$ but not the H63D mutation $(\mathrm{p}=0.27)$ was significantly more common in those with a transferrin saturation greater than 55\%. Transferrin saturation remained elevated in 13 of the 38 subjects who had repeat fasting iron measurements (fig 1). In eight subjects this was associated with a persistently elevated serum ferritin concentration (males $>300 \mu \mathrm{g} / 1$, females $>160 \mu \mathrm{g} / \mathrm{l}$ ) and these subjects all underwent liver biopsy. Histology and hepatic iron indexes were consistent with haemochromatosis in three cases, all of whom were C282Y homozygotes; these subjects were discussed above. Biopsy results did not support a diagnosis of haemochromatosis in the other five patients with stainable iron graded $0-2$ and hepatic iron indexes of between 0.4 and $1.2 \mu \mathrm{mol} / \mathrm{g}$ dry tissue/year. Thus, the prevalence of clinically apparent haemochromatosis based on the liver biopsy findings of subjects with persistently elevated transferrin saturation and serum ferritin concentration was one in $355(0.28 \%)$. The five patients with elevated transferrin saturations but without consistently elevated serum ferritin concentrations were not biopsied but this group included two C282Y homozygotes (fig 1).

\section{Discussion}

Haemochromatosis has increasingly been recognised as a common disorder but previous 
estimates of its prevalence have been based on phenotypic expression of the disease. In this study we have established the frequency of $H F E$ gene mutations and analysed their relation to serum iron indexes and to clinically significant iron overload. The C282Y and H63D mutations occurred at gene frequencies of 0.070 and 0.144 respectively. Heterozygosity for the C282Y and H63D mutations was present in $13.2 \%$ and $24.3 \%$ of the study population respectively and nearly two fifths $(38.4 \%)$ of the study population carried one or more $H F E$ gene mutations.

Although every attempt was made to obtain a random sample, the study population was not completely representative of the target population with sex and employment status affecting participation. There were, however, no significant sex or occupational differences in $H F E$ genotype frequencies and it is therefore unlikely that these recruitment differences significantly affected the observed mutation frequencies. No patients with previously diagnosed haemochromatosis were recruited but eight subjects had a family history of the disorder, two of whom were found to be C282Y homozygotes, two were C282Y heterozygotes, and the remaining four had no $H F E$ gene mutations. These subjects may have been more likely to volunteer for the study but this would have a minimal effect on the estimated gene frequency as they represent only six (4\%) of the 150 chromosomes affected by C282Y mutations detected in the study population. Furthermore, the prevalence of C282Y homozygosity predicted from the gene frequency $(1: 201)$ is very close to the observed prevalence of $1: 213$ and to that reported in Australian and British populations. ${ }^{31} 32$

Haemochromatosis predominantly affects Caucasians of European descent, ${ }^{3473233}$ and may have arisen in an ancient Celtic population with subsequent migration explaining the geographical distribution of the disorder. ${ }^{32}$ The New Zealand population is predominantly of British-Irish ancestry and the observed genotype frequencies are very similar to those reported in a recent study of 413 British subjects. ${ }^{32}$ It has been suggested that the relatively high prevalence of haemochromatosis in populations of Celtic descent may reflect a selective advantage protecting heterozygotes from iron deficiency when dietary iron intake is limited. ${ }^{34-36}$ Two studies have shown that low serum ferritin concentrations are less common in heterozygous women compared with controls. ${ }^{30} 37$ In contrast to these studies, which assigned probable genotype by HLA typing, we did not find any significant differences in HFE genotype distribution between iron deficient and iron replete subjects, even when the analysis was restricted to women in the reproductive age range. However, it is possible that any effect is masked in New Zealand where meat intake is high and iron supplementation during pregnancy is common.

There is, however, clear evidence that $H F E$ mutations affect serum iron indexes and subjects with one or more mutations had significantly higher mean serum iron concen- trations and transferrin saturations compared with normal subjects. Serum ferritin concentrations were also consistently higher but this was only significant for C282Y homozygotes. Approximately $10 \%$ of $\mathrm{C} 282 \mathrm{Y}$ heterozygotes had elevated transferrin saturations or serum ferritin concentrations above the upper limit of normal as determined from individuals without any HFE mutations. This supports and extends earlier observations of partial biochemical expression in a proportion of heterozygotes ascertained in family studies. ${ }^{26-30}$

The $H F E$ gene was identified by positional cloning and it is probable that HFE mutations are the underlying cause of most cases of haemochromatosis. ${ }^{38}$ In all series reported to date the majority of cases have been homozygous for the C282Y mutation. ${ }^{13}{ }^{15-18}$ All three biopsy confirmed cases of haemochromatosis in this study were $\mathrm{C} 282 \mathrm{Y}$ homozygotes giving a prevalence of 1 in $355(0.28 \%)$. A fourth C282Y homozygote is almost certainly affected but did not have an elevated serum ferritin and was not biopsied. The fifth subject has a normal serum ferritin possibly related to her age and poor diet, although an unidentified malabsorption disorder cannot be excluded. The number of homozygous subjects who will develop clinical disease is unknown. ${ }^{39}$ It has previously been shown that nearly all individuals identified as putative homozygotes by HLA typing will develop evidence of iron overload in the absence of an environmental or genetic modifying factor. ${ }^{40}$ However, a recent Australian study has reported that $17.3 \%$ of subjects homozygous for the C282Y mutation do not express iron overload sufficient to meet current diagnostic criteria of haemochromatosis. ${ }^{41}$ Our study confirms that haemochromatosis is a common condition affecting populations of European descent and that approximately 1 in 200 of this population carry a genotype that places them at a high lifetime risk for the development of iron overload. However, two of the five C282Y homozygotes in this study would not have been detected by screening protocols based on serum iron indexes alone.

The significance of the H63D mutation has been controversial and it has been suggested that this is simply a genetic polymorphism. ${ }^{16}{ }^{18}$ We found that individuals either homozygous or heterozygous for the H63D mutation had significantly higher mean serum iron concentrations and transferrin saturations compared with subjects with no $H F E$ gene mutations. Higher serum ferritin concentrations were observed but this did not reach statistical significance. Similar trends were observed when comparing compound heterozygotes with simple C282Y heterozygotes. Despite this we did not find a significant clinical effect of the H63D mutation. This mutation did not confer protection from iron deficiency, it did not increase the prevalence of a transferrin saturation greater than $55 \%$, and no subject had iron overload.

However, the high frequency and effects of both the C282Y and H63D mutations suggest that these two mutations are important determinants of the iron status of populations of 
European descent. Iron status may be important in other diseases and associations with ischaemic heart disease ${ }^{42}$ and the response of hepatitis $\mathrm{C}$ to interferon have been reported. ${ }^{43}$ Further study is required to determine the significance of $H F E$ gene mutations in these situations as currently the only confirmed associations are those between the C282Y mutation and porphyria cutanea $\operatorname{tarda}^{44}$ and nonalcoholic steatohepatitis. ${ }^{45}$

Haemochromatosis is an attractive candidate for large scale population based screening programmes. ${ }^{46-48}$ It is common and causes significant morbidity; yet there is a simple and effective treatment that alters the natural history of the disease and preserves life expectancy in precirrhotic individuals. ${ }^{9}{ }^{1249}$ The current screening test of choice is transferrin saturation. ${ }^{49}$ We adopted a screening strategy ${ }^{2}$ based on a transferrin saturation cut off value of $55 \%$ and established the diagnosis by liver biopsy in subjects with a persistently elevated transferrin saturation and serum ferritin concentration. This identified three individuals with haemochromatosis, all of whom were C282Y homozygotes. An alternate screening strategy based on $H F E$ mutation analysis of either the entire study population or just those individuals with an elevated transferrin saturation, would have identified all three confirmed cases together with an additional two C282Y homozygotes who may subsequently develop overt iron overload. Screening using DNA analysis has the advantage of detecting subjects with delayed or incomplete phenotypic expression, allowing diagnosis at an early age and treatment to prevent clinically significant iron overload. However, there are potential problems with the widespread introduction of molecular screening. Firstly, in some populations the number of haemochromatosis patients without $H F E$ gene mutations is significant. ${ }^{18}$ Secondly, until the cost of genotyping can be reduced transferrin saturation will remain the most cost effective screening test. At the moment screening programmes should probably restrict genotyping to those individuals with an elevated transferrin saturation although mutation analysis may well become the screening test of choice in the future.

The authors wish to thank Rona Buttimore, James Yeo, and Howard Potter for their assistance with this project. This research was supported by a grant from the Health Research Council of New Zealand.

1 Edwards CQ, Griffen LM, Goldgar D, et al. Prevalence of hemochromatosis among 11,065 presumably healthy blood donors. N Engl f Med 1988;318:1355-62.

2 Leggett BA, Halliday JW, Brown NN, et al. Prevalence of haemochromatosis amongst asymptomatic Australians. $B$ f Haematol 1990;74:525-30.

3 Baer DM, Simons JL, Staples RL, et al. Hemochromatosis screening in asymptomatic ambulatory men 30 years of age and older. Am F Med 1995;98:464-8.

4 Smith BN, Kantrowitz W, Grace ND, et al. Prevalence of hereditary hemochromatosis in a Massachusetts corporation: is Celtic origin a risk factor? Hepatology 1997; 25:1439-46.

5 Olsson KS, Ritter B, Rosen U, et al. Prevalence of iron overload in Central Sweden. Acta Med Scand 1983;213:145-50.

6 Olsson KS, Eriksson K, Ritter B, et al. Screening for iron overload using transferrin saturation. Acta Med Scand overload using trans

7 Powell LW, Jazwinska E, Halliday JW. Primary iron overload. In: Brock JH, Halliday JW, Pippard MJ, Powell
LW, eds. Iron metabolism in health and disease. London: Saunders, $1994: 227-70$.

8 Edwards CQ, Cartwright GE, Skolnick MH, et al. Homozygosity for hemochromatosis: clinical manifestations. Ann Intern Med 1980;93:519-25.

9 Niederau C, Fischer R, Purschel A, et al. Long-term survival in patients with hereditary hemochromatosis. Gastroenterology 1996;110:1107-19.

10 Niederau C, Fischer R, Sonnenberg A, et al. Survival and causes of death in cirrhotic and in noncirrhotic patients with primary hemochromatosis. N Engl f Med 1985;313: 1256-62.

11 Fargion S, Mandelli C, Piperno A, et al. Survival and prognostic factors in 212 Italian patients with genetic hemochromatosis. Hepatology 1992;15:655-9.

12 Adams PC, Speechley M, Kertesz AE. Long-term survival analysis in hereditary hemochromatosis. Gastroenterology 1991;101:368-72.

13 Feder JN, Gnirke A, Thomas W, et al. A novel MHC class -like gene is mutated in patients with hereditary hemochromatosis. Nat Genet 1996;13:399-408.

14 Bodmer JG, Parham P, Albert ED, et al. Putting a hold on "HLA-H". Nat Genet 1997;15:234-5.

15 Jazwinska EC, Cullen LM, Busfield F, et al. Haemochromatosis and HLA-H. Nat Genet 1996;14:249-51.

16 Jouanolle AM, Gandon G, Jezequel P, et al. Haemochromatosis and HLA-H. Nat Genet 1996;14:251-2.

17 Beutler E, Gelbart T, West C, et al. Mutation analysis in hereditary hemochromatosis. Blood Cells Mol Dis 1996;22: 187-94

18 Carella M, D'Ambrosio L, Totara A, et al. Mutation analysis of the HLA-H gene in Italian hemochromatosis patients. Am f Hum Genet 1997;60:828-32.

19 Beutler E. Genetic irony beyond haemochromatosis: clinical effects of HLA-H mutations. Lancet 1997;349:296-7.

20 Martinez PA, Biron C, Blanc F, et al. Compound heterozygotes for hemochromatosis gene mutations: may they help to understand the pathophysiology of the disease? Blood Cells Mol Dis 1997;23:269-76.

21 Scheuer PJ, Williams R, Muir AR. Hepatic pathology in relatives of patients with haemochromatosis. F Pathol Bacterelatives of patients
riol $1962 ; 84: 53-64$.

22 Bassett ML, Halliday JW, Powell LW. Value of hepatic iron measurements in early hemochromatosis and determination of the critical iron level associated with fibrosis. Hepatology 1986;6:24-9.

23 Chapman BA, Horton DM, Burt MJ, et al. Investigation of subjects with abnormal iron studies: role of the hepatic iron index. NZ Med F 1994;107:504-7.

24 Talmud P, Tybjaerg-Hansen A, Bhatnagar D, et al. Rapid screening for specific mutations in patients with a clinical diagnosis of familial hypercholesterolaemia. Atherosclerosis 1991;89:137-41.

25 Burt MJ, Upton JD, Morison IM, et al. Molecular analysis of HLA-H gene mutations in New Zealand patients with haemochromatosis. NZ Med F 1997;110:429-32.

26 Cartwright GE, Edwards CQ, Kravitz K, et al. Hereditary hemochromatosis. Phenotypic expression of the disease. $N$ Engl f Med 1979;301:175-9.

27 Simon M, Fauchet R, Hespel JP, et al. Idiopathic hemochromatosis: a study of biochemical expression in 247 heterozygous members of 63 families: evidence for a single major HLA-linked gene. Gastroenterology 1980;78:703-8.

28 Bassett ML, Halliday JW, Powell LW. HLA typing in idiopathic hemochromatosis: distinction between homozygotes and heterozygotes with biochemical expression. Hepatology 1981;1:120-6.

29 Adams PC. Prevalence of abnormal iron studies in heterozygotes for hereditary hemochromatosis: an analysis of 255 heterozygotes. Am 7 Hematol 1994;45:146-9.

30 Bulaj ZJ, Griffen LM, Jorde LB, et al. Clinical and biochemical abnormalities in people heterozygous for hemochromatosis. N Engl f Med 1996;335:1799-805.

31 Cullen LM, Summerville L, Glassick TV, et al. Neonatal screening for the hemochromatosis defect. Blood 1997;90: 4236.

32 Merryweather-Clarke AT, Pointon JJ, Shearman JD, et al. Global prevalence of putative haemochromatosis mutations. F Med Genet 1997;34:275-8.

33 Bacon BR, Sadiq SA. Hereditary hemochromatosis: presentation and diagnosis in the 1990s. Am 7 Gastroenterol 1997; 92:784-9.

34 Simon M, Alexandre JL, Fauchet R, et al. The genetics of hemochromatosis. Prog Med Genet 1980;4:135-68.

35 Motulsky AG. Genetics of hemochromatosis. N Engl f Med 1979;301:1291.

36 Kravitz K, Skolnick M, Cannings C, et al. Genetic linkage between hereditary hemochromatosis and HLA. Am f Hum Genet 1979;31:601-19.

37 Crawford DHG, Powell LW, Leggett BA, et al. Evidence that the ancestral haplotype in Australian hemochromatosis patients may be associated with a common mutation in the gene. Am f Hum Genet 1995;57:362-7.

38 Jazwinska EC, Powell LW. Hemochromatosis and "HLAH": definite! Hepatology 1997;25:495-6.

39 Kushner JP. Screening for hemochromatosis. Gastroenterology 1995;109:315-16.

40 Powell LW, Summers KM, Board PG, et al. Expression of hemochromatosis in homozygous subjects. Implications for early diagnosis and prevention. Gastroenterology 1990;98: early diag $1625-32$.

41 Crawford DHG, Jazwinska EC, Cullen LM, et al. Expression of HLA-linked hemochromatosis in subjects homo- 
zygous or heterozygous for the C282Y mutation. Gastroenterology 1998;114:1003-8.

42 Salon JT, Nyyssonen $\mathrm{K}$, Korpela $\mathrm{H}$, et al. High stor levels are associated with excess risk of myocardia infarction in Eastern Finnish men. Circulation 1992;86: 803-11.

43 Olynyk JK, Reddy KR, Di Bisceglie AM, et al. Hepatic iron concentration as a predictor of response to interferon alfa therapy in chronic hepatitis C. Gastroenterology 1995;108: 1104-9.

44 Roberts AG, Whatley SD, Morgan RR, et al. Increased frequency of the haemochromatosis Cys282 $\mathrm{Tyr}$ mutation in sporadic porphyria cutanea tarda. Lancet 1997;349:321-3.

45 George DK, Goldwurm S, MacDonald GA, et al. Increased hepatic iron concentration in nonalcoholic steatohepatitis is associated with increased fibrosis. Gastroenterology 1998; 114:311-18

46 Balan V, Baldus W, Fairbanks V, et al. Screening for hemochromatosis: a cost-effectiveness study based on 12,258 patients. Gastroenterology 1994;107:453-9.

47 Phatak PD, Guzman G, Woll JE, et al. Cost-effectiveness of screening for hereditary hemochromatosis. Arch Intern Med 1994;154:769-76.

48 Adams PC, Gregor JC, Kertesz AE, et al. Screening blood donors for hereditary hemochromatosis: decision analysis model based on a 30-year database. Gastroenterology 1995; 109:177-88

49 Edwards CQ, Kushner JP. Screening for hemochromatosis. N Engl f Med 1993;328:1616-20. 